\title{
Pros and Cons of Vaccine Refusal in Social Media
}

\author{
Cut Meutia Karolina*, Irwa Rochimah Zarkasi \\ Universitas Al Azhar Indonesia, Sisingamangaraja No.2, RT.2/RW.1, Selong, \\ Kebayoran Baru, South Jakarta City, DKI Jakarta, Indonesia \\ *Corresponding author, e-mail: cut.meutia@uai.ac.id
}

\begin{abstract}
The video of rejection of COVID-19 vaccine by Ribka Tjiptaning, a public figure in Indonesia, has become one of the most popular trending news topics in various media in Indonesia. The purpose of this study is to explore the cyber community beliefs regarding COVID-19 prevention vaccination through Ribka Tjiptaning's video statement on Instagram and Facebook posts. The research was conducted on Instagram and Facebook comments with a netnographic approach by relying on the selective process theory, the concept of conspiracy, and vaccine hesitancy. Two main themes were identified: pro comments, through statements that support the content on the video, and counter comments, through statements that reject the content on the video.
\end{abstract}

Keywords: COVID-19; Netnography; Ribka Tjiptaning; Vaccine Refusal; Vaccination

\begin{abstract}
Abstrak
Video penolakan vaksin pencegahan COVID-19 oleh Ribka Tjiptaning, seorang tokoh masyarakat di Indonesia menjadi satu berita terpopuler trending topik berbagai media di Indonesia. Tujuan dari penelitian ini adalah untuk mengeksplorasi bagaimana kepercayaan komunitas cyber tentang vaksinasi pencegahan COVID-19 melalui video pernyataan Ribka Tjiptaning pada postingan instagram dan facebook. Penelitian dilakukan pada komentar instagram dan facebook dengan pendekatan netnografi dengan bersandar pada teori selective process, konsep konspirasi, dan vaccine hesitancy. Dua tema utama diidentifikasi: komentar pro, melalui pernyataan yang mendukung isi pada video, dan komentar kontra melalui pernyataan yang menolak isi pada video. Hasil penelitian menunjukkan bahwa pro kontra vaksinasi pencegahan COVID-19 pada video pernyataan tolak vaksin dari Ribka Tjiptaning dapat dikategorikan menjadi tiga kategori, yaitu Kelompok Pro dan Kontra efek polarisasi politik, kelompok Pro dan Kontra berkaitan dengan kepercayaan pada teori konspirasi dan Vaccine Hesitancy..
\end{abstract}

Kata Kunci: COVID-19; Netnography; Ribka Tjiptaning; Penolakan Vaksin; Vaksinasi 


\section{Introduction}

Ribka Tjiptaning's video statement refusing the COVID-19 prevention vaccine had become popular news in Indonesia and became a trending topic on various social media (CNN Indonesia, 2021a). Ribka Tjiptaning is an Indonesian public figure who has also served as a member of the DPR-RI since 2019 until now (DPR RI, 2019). Ribka's membership in the DPR seat coincided with the issuance of various government policies in dealing with the COVID-19 pandemic in Indonesia.

Ribka Tjiptaning has become increasingly popular in the community through her response to the COVID-19 preventive vaccination program launched by the government in early 2021. Ribka became the first to issue a statement rejecting the mandatory COVID-19 preventive vaccine. The statement was conveyed through Ribka's response in a working meeting between Commission IX of the Indonesian House of Representatives and the Indonesian Ministry of Health, BPOM (Indonesian Food and Drug Supervisory Agency), and Biofarma (State-Owned Enterprise providing Indonesian vaccines) on January 12, 2021 (CNN Indonesia, 2021b).

Ribka's rejection of the COVID-19 preventive vaccine was a firm statement. Even Ribka was willing to pay a sum of money if the act of refusing to get the vaccine was to be covered by a fine. As quoted from Ribka's statement that "I still do not want to be vaccinated nor can those 63 years old be vaccinated. I'm already 63. If you want all ages, you can. Even if all my children and grandchildren living in DKI get a penalty of IDR5million, it is better if I pay it, sell the car, maybe."(Akbar, 2021). Statements reported through many social media platforms and online media continue to stick out and develop in the community. The day after making this statement, Ribka also became a trending topic on Twitter on January 13, 2021 (CNN Indonesia, 2021a). Responses from various party cadres also emerged, including responses from representatives of the Nasdem Party, who considered Ribka's statement an unwise provocation (Chaterine, 2021a), and the response from the Gerindra Party regretted Ribka's actions (detikcom, 2021).

The topic around Covid continues to be a search trend in cyberspace and even continues to increase every month (Limilia \& Pratamawaty, 2020). No wonder Ribka's statement is one of the topics that invite debate in the midst of cyber society. Not only that, but Ribka's statement also impacted the rotation of the PDIP Faction Cabinet. In the list of members' names rotated by the PDIP Faction, the name Ribka Tjiptaning Ploretariyati is listed from Commission IX to Member of Commission VII (Chaterine, 2021b).

The pros and cons of vaccines in Indonesia have become a topic that is often discussed. Prior to the emergence of pros and cons regarding vaccination in the context of preventing COVID-19, various other types of vaccines also invited debates at the beginning of their emergence. Debates are generally related to whether or not to agree or not to a certain vaccine for a group of people. As reflected in the pro-contra phenomenon of Measles and MR Rubella Vaccines in 2017. BBC Indonesia reports that in response to the Measles and Rubella MR Vaccines, there are doubts and pros and cons in the community discussing the issue of halal or not vaccines, vaccine content, and the issue of Post-Immunization Adverse Events (AEFI) (Sustainable \& Budhi, 2017). Not only in Indonesia, have similar pro and con phenomena also occurred in various parts of the world. The results of a study reveal events in Australia in response to the Rubella MR vaccine (Beard et al., 2017) and an overview of public doubts about vaccines that occur in Africa (Cooper et al., 2018). 
The vaccination program for the prevention of COVID-19 in Indonesia has also experienced unique polemics and controversies in society. Prior to Ribka Tjiptaning's statement, the phenomenon that occurred was the same as in other vaccine programs. The acceptance of the COVID-19 prevention vaccination program did not immediately enter and be accepted by the public. Many debates divide public opinion on whether or not to receive the COVID-19 vaccination. This can be seen from various research results. A study on the pro-contra sentiments of Covid prevention vaccination found that there were pros and cons in responding to COVID-19 prevention vaccinations on Twitter social media, with the result that $30 \%$ gave a positive response to the discourse and $26 \%$ of responses gave negative(Rachman \& Permana, 2020). Another study regarding the Classification of Sentiment of Twitter Social Media Users towards the Procurement of the COVID-19 Vaccine showed that the percentage of public opinion on the corona vaccine was $48 \%$ positive, $29 \%$ neutral, and $23 \%$ negative (Aditama et al., 2020). In addition, the results of other studies found that one of the causes of the emergence of pros and cons in the community regarding vaccines was the wrong public perception of COVID-19 vaccination activities. One of the reasons is the lack of understanding from the public (Astuti et al., 2021).

The phenomenon of the pros and cons of the Covid-19 preventive vaccine, which already has a wick, is getting more and more burning with the emergence of Tjiptaning's response. Since its release in the media, Ripka Tjiptaning's video statement has become a hot conversation and quickly spread to the public. Most online media reported it by embedding the video clip in it. Then various social media platforms were busy discussing the refusal of vaccines related to the video clip statement from Ribka Tjiptaning, including on Facebook and Instagram social media posts. In fact, the hashtag \#tolakvaccin on Instagram is filled with video clips of Ribka Tjiptaning's statement about vaccines.

Online media Kontan reported that Ribka Tjiptaning issued a statement refusing vaccines related to anti-COVID-19 vaccination with several underlying reasons, including 1) Ribka's age at that time had reached 63 years, where the vaccine provision was for people under 60 years old; 2) Coercion to vaccinate is a violation of human rights; 3) Clinical trials of the Sinovac vaccine (the vaccine used at the start of the vaccine program in Indonesia) have not yet been completed; and 4) Ribka's suspicions of sniffing out there is a business game in the import of vaccines(Kontan, 2021).

The topic of public response to COVID-19 preventive vaccination is a hot topic and has attracted the attention of many researchers. Various research results try to reveal it. As research results from Germani \& Biller in 2021 on the anti-vaccination infodemic on social media revealed that the success of a COVID-19 preventive vaccination program depends on the power of taste from the community, society, in general, serves as a sounding board for anti-vaccination discourse to circulate online (Germany \& Biller-Andorno, 2021). Furthermore, research on the acceptance of the COVID-19 preventive vaccine in Southeast Asia revealed that the basic effectiveness of the vaccine strongly influenced the acceptance of the COVID-19 vaccine. Preparing the general public to receive a vaccine of relatively low effectiveness is predicted to be difficult (Harapan et al., 2020).

Research on the response of cyber society is one method that is quite a trend. Following the progress of increasingly developing technology and internet users who are increasingly becoming part of society, various new phenomena have emerged in the virtual world. One of the popular and suitable methods for studying cyber society and 
its behavior is the netnographic method. As netnography can be defined as research, the condition is that the researcher is familiar with computer-mediated communication (CMC) and is a member of the community in the social media being studied (Kozinets, 2020). Several previous studies using the netnographic method have also described various phenomena of public action in the internet world. For example, research from Fatimah in 2021 regarding the Gojek advertising strategy on social media revealed that advertising strategies in internet media are one of the right ways to offer products (Fatimah et al., 2021). The research uses the netnographic method with the theme of studyThe United Nations Environment beat plastic pollution action on Instagram found that the UN Environment agency had made the right decision by using Instagram as a medium to carry out the Beat Plastic Pollution action (Annisa, 2019). In addition, the netnographic method in research with the title "Public Perception of Information about COVID-19 on social media Instagram: An Netnography Study of Visual Information" also revealed that information on Instagram accounts was considered more attractive, easier to check, and more updated. $84 \%$ of respondents admitted to spreading the information back to their families, but the information did not appear on the informants' social media accounts (Lathifah et al., 2021).

The political situation and the response of the cyber community on social media are quite important and interesting things to study. As (Geusan Akbar et al., 2021)revealed that social media is not only a platform to share stories in everyday life but can also be a medium for viewing public opinions and perceptions through various comments. Various information in social media, if collected and analyzed, can be input and help various parties to understand the surrounding conditions and can even assist the government in making decisions. Furthermore, a study (Lim, 2017) also revealed that apart from encouraging freedom of expression, social media also promotes the freedom to hate. Individuals exercise their right to voice their opinions while actively silencing others. Social media has the potential to facilitate a more participatory democracy while recognizing the disruptive value of challenging traditional interests and the use of the power of communication (Loader \& Mercea, 2011).

Based on previous research, the researcher considers that research on the pros and cons of public responses in the comments column related to the statement on the rejection of the COVID-19 prevention vaccine submitted by Ribka Tjiptaning is important interesting to study. Research with the method and subject of this research is also relatively new and has never been done. As can be seen, previous studies have looked at the widespread use of social media as a subject using qualitative case studies or content analysis methods. In this study, the research subject will be studied specifically in three posts on Facebook and Instagram related to the video statement of rejection of the COVID-19 vaccine by Ribka Tjiptaning with the qualitative method of netnography.

This researcher aims to map the pros and cons of cyber society in response to Ribka Tjiptaning's statement regarding the government's COVID-19 preventive vaccination program. The researcher tries to find variations of pro and con statements in the comments column and categorize them. Next, the researcher analyzed the pros and cons to understand people's experiences as reflected in social media footprints, practices, networks, and systems.

This study uses data from selected posts on Instagram and Facebook related to Ribka Tjiptaning's statement regarding vaccine refusal. Researchers analyzed all comments in the three posts from three accounts, namely @gtvindonesia_news, Surya 
Online and Tribun Medan. Furthermore, the comments are mapped and categorized based on the results of the analysis obtained by the researcher. The results of the mapping and categorization become a description of the cultural experience for further analysis by researchers.

\section{Method}

The research on the pros and cons of COVID-19 vaccination in Ribka Tjiptaning's statement is qualitative research using the netnographic method as netnography is defined as a research methodology with new terminology focused on the study of social media. Netnography is a qualitative method that seeks to understand cultural experiences reflected in social media footprints, practices, networks, and systems. These cultural experiences can be involved, communicated, and reflected, thus forming the three basic elements of netnography: investigation, interaction, and immersion (Kozinets, 2020). In the context of this research, cultural experience relates to how cyber society responds to issues that arise on social media. It then reflects on their responses through comments based on beliefs and personal experiences related to the issue of refusing vaccines in government discourse for the anti-COVID-19 vaccination program that they encountered both from the social environment and cyberspace.

According to Robert Kozinets, with netnography, social media is considered a research tool and can be a sustainable system for market intelligence and as insight for marketers who need it. The requirements for conducting this research are familiar with computer-mediated communication (CMC) and becoming a community member in social media. Netnography analyzes the structure and pattern of relations between community members called actors (nodes) and relationships between members called (Kozinets, 2020).

This research was carried out through two stages of searching. The first stage begins by searching for posts related to the pros and cons of COVID-19 prevention vaccinations on Instagram social media. Researchers searched for the hashtag \#Tolakvaccin. Next, the researcher collected the posts that appeared the most related to the hashtag, namely posts related to video clips of statements from Ribka Tjiptaning relating to the rejection of vaccines at the DPR RI Commission IX meeting with the Ministry of Health, BPOM, and Biofarma. The researcher took the post with the most comments, namely the online media account @ gtvindonesia_news. Furthermore, in the second stage, the researchers continued to search for the same content related to Ribka Tjiptaning's video statement, which was spread through social media Facebook. The selection process finally determined two posts from Facebook, namely from Surya Online and Tribun Medan. Both are online media accounts. To be more concise, the post data that are the subject of this research can be seen in Table 1 below. 
Table 1. Research Subject Post Data

\begin{tabular}{|c|c|c|c|c|c|}
\hline No & Social Media & Account & $\begin{array}{l}\text { Post } \\
\text { Date }\end{array}$ & Post Title & $\begin{array}{c}\text { Likes \& } \\
\text { Comments }\end{array}$ \\
\hline 1. & Instagram & @gtvindonesia_news & $\begin{array}{l}\text { January } \\
152021\end{array}$ & $\begin{array}{l}\text { Controversy } \\
\text { Refusing } \\
\text { COVID-19 } \\
\text { Vaccine } \\
\text { Ribka } \\
\text { Tjiptaning } \\
\text { Was Once a } \\
\text { Candidate for } \\
\text { Minister of } \\
\text { Health. }\end{array}$ & $\begin{array}{l}292 \text { Comments/ } \\
1951 \text { Likes }\end{array}$ \\
\hline 2. & Facebook & Surya Online & $\begin{array}{l}\text { January } \\
132021\end{array}$ & $\begin{array}{l}\text { Surprisingly, } \\
\text { Dr. Ribka } \\
\text { Ciptaning } \\
\text { refuses to be } \\
\text { vaccinated. }\end{array}$ & $\begin{array}{c}969 \\
\text { Comments/5.1K } \\
\text { Likes }\end{array}$ \\
\hline 3. & Facebook & Medan Tribun & $\begin{array}{l}\text { January } \\
142021\end{array}$ & $\begin{array}{c}\text { Full } 18 \\
\text { Minutes } \\
\text { Recording of } \\
\text { Ribka } \\
\text { Tjiptaning's } \\
\text { Rejection of } \\
\text { the COVID- } \\
\text { 19 Vaccine }\end{array}$ & $\begin{array}{c}3.5 \mathrm{~K} \\
\text { Comments/12K } \\
\text { Likes }\end{array}$ \\
\hline
\end{tabular}

Researchers analyzed all the comments in the three posts from @gtvindonesia_news, Surya Online, and Tribun Medan. Furthermore, the comments are mapped and categorized based on the analysis results obtained by the researcher. The results of mapping and categorizing become a new direction for researchers to investigate further. A similar method was also used in research on ethnography analysis on Online Eating Broadcasts conducted by Strand and Gustafsson in 2020 (Strand \& Gustafsson, 2020).

\section{Results and Discussion}

This study examines three content on three different accounts on social media Facebook and Instagram. Researchers analyzed the three comment fields on each post with a total of 4761 comments. Then, the research results try to interpret and categorize the researchers into several categories.

The researcher revealed that some opinions in the comments column on posting the statement refusing the vaccine from Ribka Tjiptaning mutually agreed or disagreed with the statement. The public conveys the pros or cons through reasoned comments so that any comments that are pro or con will defend each other's opinion. As quoted in the comments on posts on Facebook media reported by the Medan Tribune account, it was found as follows:

Pro

"Ms. Ribka Cipta is a representative of the people who dare to express their opinion about the problems faced by the people from the small and middle class 
that are really happening in society. I really admire her. That is a GOOD SPEAKER. Not a rubbish one. Good..."

\section{Counter}

"This is not representing the people. If you talk for the people, you should socialize the importance of vaccination for the safety and health of the people from the COVID-19 pandemic, this is actually a provocation. Remember that you are the DPR RI, you got your salary from the people's money... it is critical, ok, but it must be useful for the people. "This is not defending the people. Drunk..."

The phenomenon of the pros and cons of society against Ribka Tjiptaning's statement that said her rejection of the mandatory Covid-19 vaccine in Indonesia could be explained from the point of view of selective behavior in the process of the public. Griffin defines selective behavior as an active action shown by the audience (Griffin, 2011). An important element of this theory is the concept of selective exposure, which refers to seeking information that supports currently held attitudes while avoiding information that does not support it (Smith, 2002). In one of the phases in selective behavior, the audience will make a decisive determination regarding the information provided by the mass media; needed or not, and in accordance with the values that exist in the audience. This has pushed public opinion into two camps: the pros and cons.

Selective behavior is a concept that initially emerged as a description of audience selectivity in conventional mass media. The results of this study found that the description of selective behavior in the audience did not only apply to conventional media, as was the finding of researchers who saw the match between selective behavior and the selective actions of cyber society in responding to Ribka Tjiptaning's statement on social media. People who have a value match in their initial view with Ribka's statement will strengthen their argument to maintain agreeing with Ribka's opinion, and vice versa. When the value contained in the individual does not match Ribka's statement, then she will express an opinion to disagree with the statement.

The researcher summarizes all comments into two categories of comments, namely pros and cons. In addition, on the pro and con categories, the researcher continued by making sub-categories of comments. There are ten sub-categories of pro comments and seven sub-categories of contra comments. For more details, it can be seen through the following table.

Table 2. Summary of Pros and Cons of Opinion on Rejecting Vaccines by Ribka Tjiptaning on Instagram and Facebook posts

\begin{tabular}{cll}
\hline No. & \multicolumn{1}{c}{ Pros } & \multicolumn{1}{c}{ Cons } \\
\hline 1 & $\begin{array}{l}\text { Everyone has right to receive and } \\
\text { refuse vaccinations. }\end{array}$ & $\begin{array}{l}\text { Ribka's statement was based on her } \\
\text { disappointment because she failed to } \\
\text { become the Minister of Health. }\end{array}$ \\
\hline 2 & $\begin{array}{l}\text { The process of clinical trials of the } \\
\text { Covid-19 vaccine has not yet been } \\
\text { completed. }\end{array}$ & $\begin{array}{l}\text { Connected with the political polemic of } \\
\text { Cebong/Kampret. }\end{array}$ \\
\hline 3 & $\begin{array}{l}\text { Various views on the negative impact } \\
\text { of vaccines. }\end{array}$ & $\begin{array}{l}\text { Inappropriate as a member of the DPR } \\
\text { and his criticism is too late. }\end{array}$ \\
\hline 4 & $\begin{array}{l}\text { There are assumptions about different } \\
\text { types of vaccines for the people and } \\
\text { officials. People are given the cheap, } \\
\text { not the best vaccine. }\end{array}$ & $\begin{array}{l}\text { Ribka was judged to be seeking } \\
\text { sensation, stress, imagery, nonsense. }\end{array}$ \\
\hline
\end{tabular}




\begin{tabular}{cll}
\hline 5 & $\begin{array}{l}\text { Covid is an artificial that aims for } \\
\text { business and political interests. }\end{array}$ & $\begin{array}{l}\text { Connected with President Jokowi who } \\
\text { will definitely take the best policies for } \\
\text { the people. }\end{array}$ \\
\hline 6 & $\begin{array}{l}\text { The vaccine comes from China, the } \\
\text { benefits are not yet clear. }\end{array}$ & $\begin{array}{l}\text { Ribka's protest was just a political trick, } \\
\text { a political stage, a political charade. }\end{array}$ \\
\hline 7 & $\begin{array}{l}\text { Perceptions about Vaccines have not } \\
\text { been proven to protect 100 percent. }\end{array}$ & $\begin{array}{l}\text { Agree vaccine but many things need to } \\
\text { be reviewed. }\end{array}$ \\
\hline 8 & $\begin{array}{l}\text { The view that people need to eat is not } \\
\text { a vaccine. }\end{array}$ \\
\hline 9 & $\begin{array}{l}\text { Council members must speak loudly } \\
\text { and decisively. }\end{array}$ \\
\hline 10 & The country has a lot of debt. & \\
\hline
\end{tabular}

When viewed from the pro comment sub-category on Ribka Tjiptaning's statement regarding vaccine rejection, various statements describe the vaccine hesitancy phenomenon. Vaccine hesitancy can be defined as a continuum between acceptance and rejection of vaccines. Vaccine hesitancy is vaccine indecision, including selfconfidence, self-satisfaction, comfort, risk calculation, and shared responsibility (Cooper et al., 2018). This means that there are still doubts about the effectiveness of vaccination in preventing COVID-19. People think vaccines have not been proven to protect 100 percent, and the public's assessment of the clinical trial process has not been completed. Thus, the public will also consider risk calculations and have confidence in following government regulations on COVID-19 prevention vaccinations.

Research result (Kulkarni et al., 2021) revealed two specific reasons for Vaccine hesitancy: experience with previous vaccinations, which can occur under the influence of individuals or groups, and scientific evidence of risks/benefits. This can be illustrated in Ribka's statement, which narrates some information on previous experiences of vaccine failure and narrates vaccine failure. This also encourages people to consider themselves more and more about taking vaccines to prevent COVID-19 or not. This consideration is reflected in the statement that states his support for the narrative presented by Ribka.

If we look at the phenomenon of the rejection of the COVD-19 preventive vaccine, the picture of the condition of doubt about the COVID-19 preventive vaccine does not only occur in Indonesia, as (West et al., 2021) explained about the doubts about the COVID-19 vaccine in temporary foreign workers from Bangladesh which also related to the level of concern about side effects. Similarly, the phenomenon of doubt about vaccines in Australia (Liddell et al., 2021) revealed that low trust in health authorities, concerns about lack of control, and the perception of COVID-19 as low risk emerged as salient barriers and attitudes related to COVID-19 vaccine doubts. It can be concluded that the Vaccine hesitancy that occurred in the comment column of Ribka Tjiptaning's statement occurred possibly related to experience and distrust of health authorities in Indonesia. Loss of trust is a major determinant of low confidence in vaccines (Badur et al., 2020).

Vaccine hesitancy also emerged through public trust in hoax information. Most of the disinformation during the COVID-19 pandemic is related to the spread of hoaxes on health issues (Rahmawati et al., 2021). This also impacts the public's view in responding to Ribka Tjiptaning's statement. One of the comments that stated on Ribka's statement on Surya Online's Facebook account was as follows "I am afraid this vaccine will not work properly, there is evidence of paralysis... we do not know China's 
intentions". This statement is without any concrete evidence, only based on the issues circulating in the community. Misinformation and disinformation regarding COVID-19 and vaccinations can contribute to vaccine doubt (Basch et al., 2021). Misinformation and misconceptions about vaccine safety, the disease and its transmission, and mistrust of science are among the most common reasons for vaccine hesitancy (Badur et al., 2020).

The pros and cons of Ribka Tjiptaning's statement do not just agree or disagree with her statement, but there are various political elements in it. One of the subcategories of comments against the public regarding Ribka's statement is to relate it to political views and political alignments. The phenomenon of political polarization in the 2019 Presidential Election which gave rise to the term "Cebong" for supporters of the Presidential / Vice Presidential Candidates Number 1 and "Kampret" for supporters of Candidates Number 2, is still a label and is still used in the mention of opinion battles regarding government politics (Ardipandanto, 2020). As (Herne et al., 2019) said, people with high political knowledge tend to be more polarized than others. Thus, it cannot be directly proportional to political knowledge and avoiding political polarization. Polarization refers to how a person becomes more extreme towards his or her original view. This can be seen in some comments on posts regarding Ribka's statement. The study revealed that in comments, people connected the polemic of "Cebong" and "Kampret" regarding the pros and cons of Ribka's opinion. The contra called the commentators pro with Ribka's opinion Kadrun (Desert Lizard)-another term for "Kampret". On the other hand, the pro groups refer to the contra commentators as "tadpoles" for defending government policies too much.

Polarization occurs with the awareness of each camp. This can be seen from the comments that boldly refer to the opposing opinion as "Cebong" or "Kampret". (Levendusky \& Malhotra, 2016) explained that media coverage of polarization increases people's beliefs about the existence of polarization. Research results (January Ali \& Eriyanto, 2021) show that polarization is a worrying condition among Indonesian netizens. The study explains that basically polarization has occurred since the 2014 General Election and continued to the 2016 DKI Jakarta Governor Election and 2019 President Election until now. This polarization shows no signs of stopping. On the contrary, it did increase. As illustrated in the results of this study, regarding any issue related to a non-political topic (the COVID-19 issue), social media users remain segregated based on political preferences.

Furthermore, the research revealed that the public's attitude towards Ribka Tjiptaning's statement was related to public beliefs about conspiracy theories. Researchers found that from all public comments on posts about Ribka Tjiptaning's statement on the rejection of vaccines, one of them expressed information that was conspiracy in nature. The conspiracy theory in question is a false belief in which an event is believed to be caused by a series of actors working together with a purpose and secret (Georgiou et al., 2020). In quote, one of the comments who judged that the COVID-19 prevention vaccination program was a planned business from the government said, "Logically, we can't be fooled" in the name of covid, vaccinate it" and in the end, everyone who dies in the hospital in is labelled Covid death" "Then a vaccine keeps coming for anti-covid" "In the end, China sent the vaccine" I couldn't believe it came from China "vaccine from China" "In the end, China is the business of disease and the Indonesian people" "Indeed, Indonesia's leader is tyrannical and the people themselves". 
Based on the results found in the field, the researcher concludes that there are three main categories that underlie the people's reasons for pro or contra against Ribka Tjiptaning's statement. The three categories are; (1) Political polarization, (2) Public belief in conspiracy theories, and (3) Vaccine hesitancy. These three reasons influence how society responds to Ribka's statement. Briefly, the three reasons can be seen in the following table.

Table 3. Categories of Reasons for the Pros and Cons of Ribka's Statement

\begin{tabular}{|c|c|c|c|}
\hline $\begin{array}{c}\text { Basic } \\
\text { reason }\end{array}$ & Community Response & Pro & Counter \\
\hline $\begin{array}{l}\text { Political } \\
\text { Polarization }\end{array}$ & $\begin{array}{l}\text { Labeling "Taebong" } \\
\text { and "Kampret on the } \\
\text { pros and cons of the } \\
\text { government. }\end{array}$ & $\begin{array}{l}\text { - Labeling Cebong } \\
\text { for those who } \\
\text { disagree with } \\
\text { Ribka's } \\
\text { statement. } \\
\text { - Giving } \\
\text { appreciation to } \\
\text { Ribka for being } \\
\text { considered to be } \\
\text { voicing the voice } \\
\text { of the people }\end{array}$ & $\begin{array}{l}\text { - Labeling Kampret for } \\
\text { those who agree with } \\
\text { Ribka's statement. } \\
\text { - Connected with President } \\
\text { Jokowi who will definitely } \\
\text { take the best policies for } \\
\text { the people. } \\
\text { - Connected with Ribka's } \\
\text { non-chosen as Minister of } \\
\text { Health. }\end{array}$ \\
\hline $\begin{array}{l}\text { Belief in } \\
\text { Conspiracy } \\
\text { Theories }\end{array}$ & $\begin{array}{l}\text { Believing that the } \\
\text { Vaccination program } \\
\text { is a government } \\
\text { business }\end{array}$ & $\begin{array}{l}\text { Believing in Covid } \\
\text { is a fabrication } \\
\text { aimed at business } \\
\text { and political } \\
\text { interests. }\end{array}$ & $\begin{array}{l}\text { - Agree vaccine but many } \\
\text { things need to be } \\
\text { reviewed. }\end{array}$ \\
\hline $\begin{array}{l}\text { Vaccine } \\
\text { hesitancy }\end{array}$ & $\begin{array}{l}\text { Fear of vaccine failure } \\
\text { and the effects of } \\
\text { vaccines because they } \\
\text { have not seen real } \\
\text { evidence of the } \\
\text { benefits of vaccines. }\end{array}$ & $\begin{array}{l}\text { Perceptions about } \\
\text { Vaccines have not } \\
\text { been shown to be } \\
100 \text { percent } \\
\text { protective and } \\
\text { concerns about the } \\
\text { effects of vaccines. }\end{array}$ & $\begin{array}{l}\text { Believe that vaccines are } \\
\text { effective and include } \\
\text { statements of other people's } \\
\text { experiences. }\end{array}$ \\
\hline
\end{tabular}

\section{Conclusion}

In short, this qualitative study that adopts a netnographic approach shows that the pros and cons of COVID-19 vaccination in the video statement of Ribka Tjiptaning can be categorized into three categories of opinions that underlie the community, namely (1) Pro and Cons groups who mix opinions with political views, which means there is political polarization; (2) Pros and Cons groups about conspiracy theories, and (3) Vaccine hesitancy. Public statements of pros and cons related to politics cannot be separated from the strong public political support in one of the camps in the 2019 presidential election. So there is a polarization of Indonesian politics, which divides society into two camps or popular terms known as "Cebong" and "Kampret". Furthermore, Pros and Cons views because conspiracy theory beliefs provide reasonable statements on conspiracy theory beliefs about COVID-19 and do not hesitate to provide statements that have not been confirmed. On the other hand, vaccine hesitancy is related to fear of the effects of vaccines that have not been tested and have seen real benefits. The researcher revealed that the most prominent of Ribka Tiptaning's video statement 
phenomenon is not only related to the topic of pros and cons about vaccination but as a phenomenon of the picture of political polarization in Indonesia, which is still very strong in terms of support for the 2019 presidential election. This finding supports previous research that states that the political polarization has occurred since the 2014 General Election and continued to the 2016 DKI Jakarta Governor The Pilkada and the 2019 General Election show no signs of stopping. On the contrary, there is a possibility of an increase. That is revealed through the phenomenon of pros and cons in the statement of COVID-19 vaccine rejection from Ribka Tjiptaning.

Furthermore, the concept of selective behavior proposed by Griffin is a concept that initially emerged as a description of audience selectivity in conventional mass media. The results of this study found that the description of selective behavior in the audience did not only apply to conventional media, as was the finding of researchers who saw the match between selective behavior and the selective actions of cyber society in responding to Ribka Tjiptaning's statement on social media.

To enrich the research results, using social network analysis methods is further research that researchers recommend. The limitation of this research lies in tracking the number of public conversations on Instagram media, which are only in a few representative posts. Researchers only explored the topic of COVID-19 prevention vaccines with video content of rejection of the COVID-19 vaccine by Ribka Tjiptaning in selected posts. Completion of research can be done in the form of a review of the communication network formed with keywords related to vaccinations or vaccines to prevent COVID-19 from getting an overview of the actors participating in the discussion of vaccines to prevent COVID-19 or on the use of the hashtag Ribka Tjiptaning on social media.

\section{References}

Aditama, M. I., Pratama, R. I., Wiwaha, K. H. U., \& Rakhmawati, N. A. (2020). Analisis Klasifikasi Sentimen Pengguna Media Sosial Twitter Terhadap Pengadaan Vaksin COVID-19. Journal Information Engineering and Educational Technology (JIEET), 4(2), 90-92. https://doi.org/https://doi.org/10.26740/jieet.v4n2.p90-92

Akbar, A. M. (2021, January 14). Tolak Vaksin, Aspirasi Wakili Rakyat atau Pribadi? Pikiran Rakyat.Co.Id. https://news.detik.com/kolom/d-5333258/tolak-vaksinaspirasi-wakili-rakyat-atau-pribadi?_ga=2.237551168.1713069873.16367105801175896579.1626238289

Annisa, S. (2019). Studi Netnografi Pada Aksi Beat Plastic Pollution oleh United Nations Environment di Media Sosial Instagram. Jurnal ASPIKOM, 3(6), 1109. https://doi.org/10.24329/aspikom.v3i6.411

Ardipandanto, A. (2020). Dampak Politik Identitas Pada Pilpres 2019: Perspektif Populisme [The Impact of Identity Politics On President Election 2019: Populism Perspective]. Jurnal Politica Dinamika Masalah Politik Dalam Negeri Dan Hubungan Internasional, 11(1), 43-63. https://doi.org/10.22212/jp.v11i1.1582

Astuti, N. P., Nugroho, E. G. Z., Lattu, J. C., Potempu, I. R., \& Swandana, D. A. (2021). Persepsi Masyarakat terhadap Penerimaan Vaksinasi Covid-19: Literature Review. Jurnal Keperawatan, 13(3), 569-580. https://doi.org/10.32583/keperawatan.v13i3.1363

Badur, S., Ota, M., Öztürk, S., Adegbola, R., \& Dutta, A. (2020). Vaccine confidence: the keys to restoring trust. Human Vaccines \& Immunotherapeutics, 16(5), 1007- 
1017. https://doi.org/10.1080/21645515.2020.1740559

Basch, C. H., Meleo-Erwin, Z., Fera, J., Jaime, C., \& Basch, C. E. (2021). A global pandemic in the time of viral memes: COVID-19 vaccine misinformation and disinformation on TikTok. Human Vaccines \& Immunotherapeutics, 17(8), 23732377. https://doi.org/10.1080/21645515.2021.1894896

Beard, F. H., Leask, J., \& McIntyre, P. B. (2017). No Jab, No Pay and vaccine refusal in Australia: the jury is out. Medical Journal of Australia, 206(9), 381-383. https://doi.org/10.5694/mja16.00944

Chaterine, R. N. (2021a, January 13). Ribka Tjiptaning Tolak Vaksin Sinovac, NasDem: Itu Provokasi Masyarakat. Detik.Com. https://news.detik.com/berita/d5332044/ribka-tjiptaning-tolak-vaksin-sinovac-nasdem-itu-provokasimasyarakat?_ga=2.266498766.1713069873.16367105801175896579.1626238289

Chaterine, R. N. (2021b, January 19). Dirotasi PDIP ke Komisi VII, Ribka Tjiptaning: Lucu Aja Dokter Ngurus Minyak. Detik.Com. https://news.detik.com/berita/d5339657/dirotasi-pdip-ke-komisi-vii-ribka-tjiptaning-lucu-aja-dokter-ngurusminyak

CNN Indonesia. (2021a, January 13). Pro-Kontra Netizen untu Ribka PDIP Penolak Vaksin Covid-19. CNN Indonesia. https://www.cnnindonesia.com/teknologi/20210113125317-192-593095/prokontra-netizen-untuk-ribka-pdip-penolak-vaksin-covid-19

CNN Indonesia. (2021b, January 13). Ribka Tjiptaning Orang Pertama Menolak Vaksin di Indonesia. CNN Indonesia. https://www.cnnindonesia.com/nasional/20210113074635-32-592938/ribkatjiptaning-orang-pertama-menolak-vaksin-di-indonesia

Cooper, S., Betsch, C., Sambala, E. Z., Mchiza, N., \& Wiysonge, C. S. (2018). Vaccine hesitancy - a potential threat to the achievements of vaccination programmes in Africa. Human Vaccines \& Immunotherapeutics, 14(10), 2355-2357. https://doi.org/10.1080/21645515.2018.1460987

detikcom. (2021, January 14). Kritik dan Pembelaan Saat Ribka Tjiptaning Tolak Divaksin Corona. Detik.Com. https://news.detik.com/berita/d-5333176/kritik-danpembelaan-saat-ribka-tjiptaning-tolak-divaksincorona?_ga=2.237551168.1713069873.1636710580-1175896579.1626238289

DPR RI. (2019). Daftar Anggota-dr. Ribka Tjiptaning Proletariyati, A.Ak. DPR RI. https://www.dpr.go.id/anggota/detail/id/265

Fatimah, S., Chusnainy, M., Khumairo, F., Mariana, S. D. H., \& Hermawan, S. (2021). Netnography: Gojek Marketing Strategy Analysis Through YouTube Social Media. Media Ekonomi Dan Manajemen, 36(1). https://doi.org/10.24856/mem.v36i1.1601

Georgiou, N., Delfabbro, P., \& Balzan, R. (2020). COVID-19-related conspiracy beliefs and their relationship with perceived stress and pre-existing conspiracy beliefs. Personality and Individual Differences, 166, 110201. https://doi.org/10.1016/j.paid.2020.110201

Germani, F., \& Biller-Andorno, N. (2021). The anti-vaccination infodemic on social media: A behavioral analysis. PLOS ONE, 16(3), e0247642. https://doi.org/10.1371/journal.pone.0247642

Geusan Akbar, G., Kurniadi, D., \& Nurliawati, N. (2021). Content Analysis of Social Media: Public and Government Response to COVID-19 Pandemic in Indonesia. 
Jurnal Ilmu Sosial Dan Ilmu Politik, 25(1), 16. https://doi.org/10.22146/jsp.56488

Griffin, E. (2011). a First Look at Communication Theory (8th Editio). McGraw-Hill. $\mathrm{R}$.

Harapan, H., Wagner, A. L., Yufika, A., Winardi, W., Anwar, S., Gan, A. K., Setiawan, A. M., Rajamoorthy, Y., Sofyan, H., \& Mudatsir, M. (2020). Acceptance of a COVID-19 Vaccine in Southeast Asia: A Cross-Sectional Study in Indonesia. Frontiers in Public Health, 8. https://doi.org/10.3389/fpubh.2020.00381

Herne, K., Christensen, H. S., \& Grönlund, K. (2019). The influence of political knowledge on opinion polarization in citizen deliberation. Political Research Exchange, 1(1), 1-23. https://doi.org/10.1080/2474736X.2019.1702887

Januar Ali, D., \& Eriyanto, E. (2021). Political Polarization and Selective Exposure of Social Media Users in Indonesia. Jurnal Ilmu Sosial Dan Ilmu Politik, 24(3), 268. https://doi.org/10.22146/jsp.58199

Kontan. (2021, January 13). Ini Alasan Anggota Fraksi PDIP Ribka Tjiptaning Tolak Vaksin Corona Sinovac. Kontan.Co.Id. https://nasional.kontan.co.id/news/inialasan-anggota-fraksi-pdip-ribka-tjiptaning-tolak-vaksin-corona-sinovac

Kozinets, R. V. (2020). Netnography (3rd Editio). Sage Publication Ltd.

Kulkarni, S., Harvey, B., Prybylski, D., \& Jalloh, M. F. (2021). Trends in classifying vaccine hesitancy reasons reported in the WHO/UNICEF Joint Reporting Form, 2014-2017: Use and comparability of the Vaccine Hesitancy Matrix. Human Vaccines \& Immunotherapeutics, 17(7), 2001-2007. https://doi.org/10.1080/21645515.2020.1859319

Lathifah, A., Tiani, R., \& Mazida, F. (2021). Public Perception of Information about COVID-19 on social media Instagram: An Netnography Study of Visual Information. E3S Web of Conferences, 317, 05015. https://doi.org/10.1051/e3sconf/202131705015

Lestari, S., \& Budhi, O. (2017, September 18). Imunisasi Campak dan Rubella MR di Tengah Pro-Kontra Vaksinasi. $\quad B B C \quad$ Indonesia. https://www.bbc.com/indonesia/indonesia-41144515

Levendusky, M., \& Malhotra, N. (2016). Does Media Coverage of Partisan Polarization Affect Political Attitudes? Political Communication, 33(2), 283-301. https://doi.org/10.1080/10584609.2015.1038455

Liddell, B. J., Murphy, S., Mau, V., Bryant, R., O’Donnell, M., McMahon, T., \& Nickerson, A. (2021). Factors associated with COVID-19 vaccine hesitancy amongst refugees in Australia. European Journal of Psychotraumatology, 12(1). https://doi.org/10.1080/20008198.2021.1997173

Lim, M. (2017). Freedom to hate: social media, algorithmic enclaves, and the rise of tribal nationalism in Indonesia. Critical Asian Studies, 49(3), 411-427. https://doi.org/10.1080/14672715.2017.1341188

Limilia, P., \& Pratamawaty, B. B. (2020). Google Trends and Information Seeking Trend of COVID-19 in Indonesia. Jurnal ASPIKOM, 5(2), 188. https://doi.org/10.24329/aspikom.v5i2.741

Loader, B. D., \& Mercea, D. (2011). Networking Democracy? Information, $\begin{array}{llll}\text { Communication } \quad \& \quad \text { Society, } & \text { 757-769. }\end{array}$ https://doi.org/10.1080/1369118X.2011.592648

Rachman, F., \& Permana, S. (2020). Analisis Sentimen Pro dan Kontra Masyarakat Indonesia tentang Vaksin COVID-19 pada Media Sosial Twitter. Indonesian of Health Information Management Journal, 8(2), 100-109. 
https://doi.org/https://doi.org/10.47007/inohim.v8i2.223

Rahmawati, D., Mulyana, D., Lumakto, G., Viendyasari, M., \& Anindhita, W. (2021). Mapping Disinformation During the Covid-19 in Indonesia: Qualitative Content Analysis. Jurnal ASPIKOM, 6(2), 222. https://doi.org/10.24329/aspikom.v6i2.907

Smith, R. D. (2002). Strategic Planning for Public Relations. Lawrence Erlbaum Associates, Inc., Publishers.

Strand, M., \& Gustafsson, S. A. (2020). Mukbang and Disordered Eating: A Netnographic Analysis of Online Eating Broadcasts. Culture, Medicine, and Psychiatry, 44(4), 586-609. https://doi.org/10.1007/s11013-020-09674-6

West, H., Lawton, A., Hossain, S., Mustafa, A. H. M. G., Razzaque, A., \& Kuhn, R. (2021). COVID-19 Vaccine Hesitancy among Temporary Foreign Workers from Bangladesh. Health Systems \& Reform, 7(1). https://doi.org/10.1080/23288604.2021.1991550 